\title{
An Integrated One-step Equation for Solving Duct/Pipe Friction Loss by Hand Calculator
}

\author{
Chung-Yueh Ho*, Cheng-Ta Ho \\ Tempace HVAC\&R Consultancy Firm, Taiwan \\ Email address: \\ tempace@yahoo.com.tw (Chung-Yueh Ho) \\ ${ }^{*}$ Corresponding author
}

To cite this article:

Chung-Yueh Ho, Cheng-Ta Ho. An Integrated One-step Equation for Solving Duct/Pipe Friction Loss by Hand Calculator. American Journal of Mechanical and Industrial Engineering. Vol. 4, No. 2, 2019, pp. 28-34. doi: 10.11648/j.ajmie.20190402.11

Received: June 18, 2019; Accepted: September 12, 2019; Published: September 26, 2019

\begin{abstract}
ASHRAE Handbooks are the worldwide reference books for HVAC engineers. When we tried to develop a duct software, we also followed the steps shown in 2013 ASHRAE Handbook. Accidently we found that some friction loss data of a duct design example seemed contrary to the data obtained from duct friction chart. Then we go back to adopt Darcy's and Colebrook's equations that have been used to solve duct/pipe friction loss for decades. However, the calculation process needs to use complicated computer program. After doing huge trial and error processes by computerized program, we obtained one integrated equation that can be used to calculate duct/pipe friction loss by hand calculator. We own an HVAC\&R consultancy firm and have the opportunity to contact many real duct/pipe projects. This empirical equation has been successfully applied to dozens of actual duct and pipe design projects. For Reynolds Number (Re) is greater than 10,000 (i.e. turbulent flow), our analysis shows the friction losses obtained from this integrated equation are within $\pm 2.0 \%$ of those obtained from Darcy's and Colebrook's equations. The accuracy $( \pm 2.0 \%)$ is good enough for engineers doing realistic duct/pipe designs. Hence, this one-step equation can be the handy alternative for Darcy's and Colebrook's equations. For the practical duct/pipe designs, engineers can calculate friction loss easily, no need to use iterative method.
\end{abstract}

Keywords: Darcy Equation, Colebrook Equation, Moody Chart, Friction Loss Chart

\section{Introduction}

Darcy's and Colebrook's equations always come into mind when discussing friction loss in ducts/pipes. For the fluid flow in duct or pipe, pressure drop due to friction loss can be calculated by Darcy equation [1]. Based on SI unit, Darcy equation can be rewritten as below.

$$
\frac{\Delta \mathrm{P}_{\mathrm{f}}}{L}=\frac{1000 * f}{D} * \frac{\rho * V^{2}}{2}
$$

where

$\Delta P_{f}=$ friction loss, $\mathrm{Pa}$

$L=$ duct/pipe length, $\mathrm{m}$

$f=$ friction factor, from equation (2)

$D=$ hydraulic diameter, $\mathrm{mm}$

$\rho=$ fluid density, $\mathrm{kg} / \mathrm{m}^{3}$

$V=$ fluid velocity, $\mathrm{m} / \mathrm{s}$

For transitional and turbulent flows, friction factor (f) can be calculated by Colebrook equation [2]:

$$
\frac{1}{\sqrt{\mathrm{f}}}=-2 \log \left[\frac{\varepsilon}{3.7 D}+\frac{2.51}{R e \sqrt{\mathrm{f}}}\right]
$$

where

$\varepsilon=$ absolute roughness factor, $\mathrm{mm}$

$R e=$ Reynolds number

Reynolds number (Re) can be calculated by the following equation [2]:

$$
R e=\frac{D * V}{1000 * v}
$$

where $v=$ Kinematic viscosity, $\mathrm{m}^{2} / \mathrm{s}$

That means three equations are needed to calculate friction loss. In addition, because friction factor (f) appears on both sides of equation (2), solving equation (2) by hand calculator is almost impossible. Therefore, the Moody chart [3] (Figure 1) is adopted. However, using Moody chart is still tedious to obtain an exact $\mathrm{f}$ value. Then, in the real-design-world, engineers prefer to adopt friction chart; Figure 2 [4] for duct 
with $\varepsilon=0.09 \mathrm{~mm}, \rho=1.20 \mathrm{~kg} / \mathrm{m}^{3}$, and Figure 3 [5] for pipe with $20^{\circ} \mathrm{C}$ water and $\mathrm{SCH} 40$ commercial steel pipe.

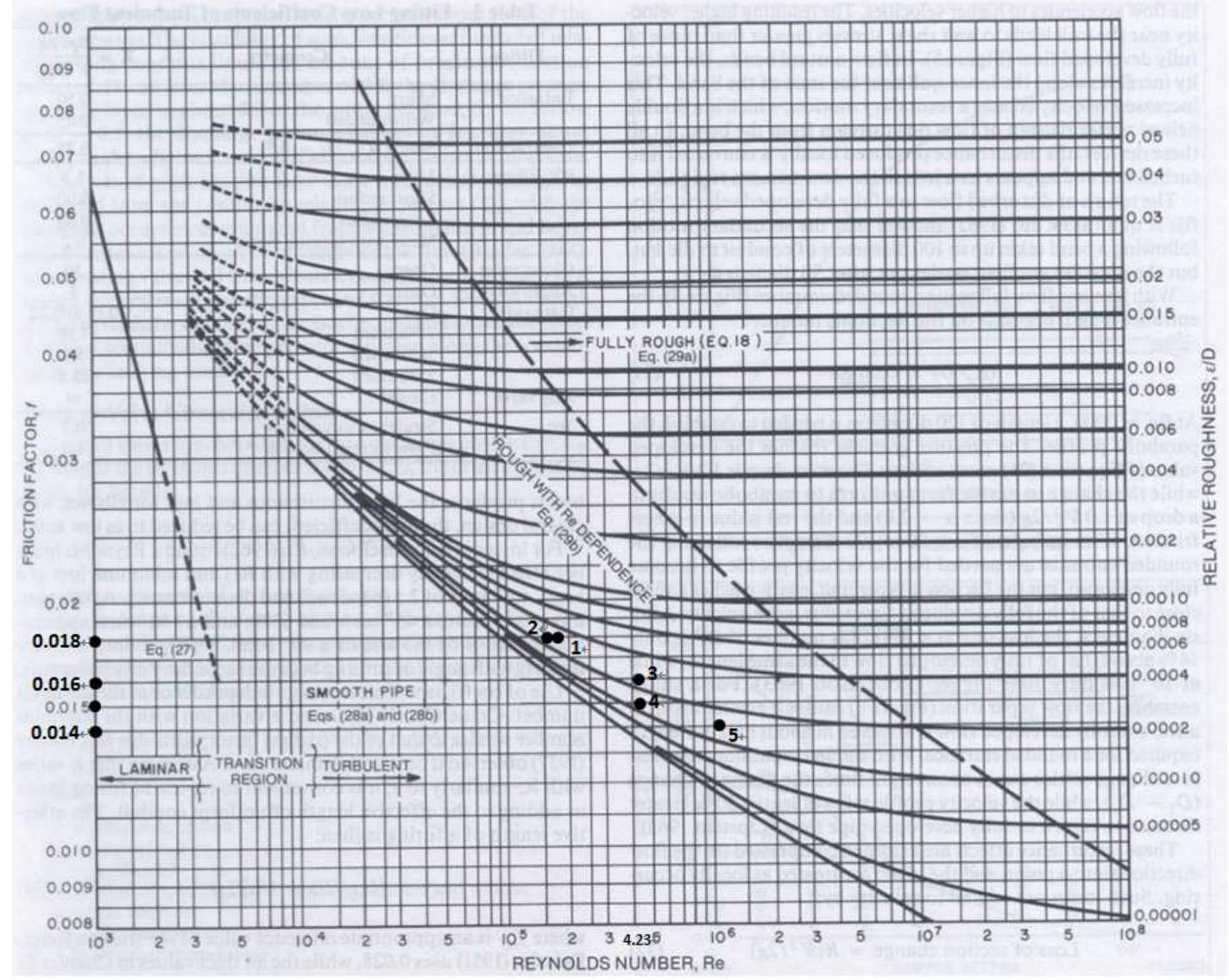

Figure 1. Moody Chart [3].

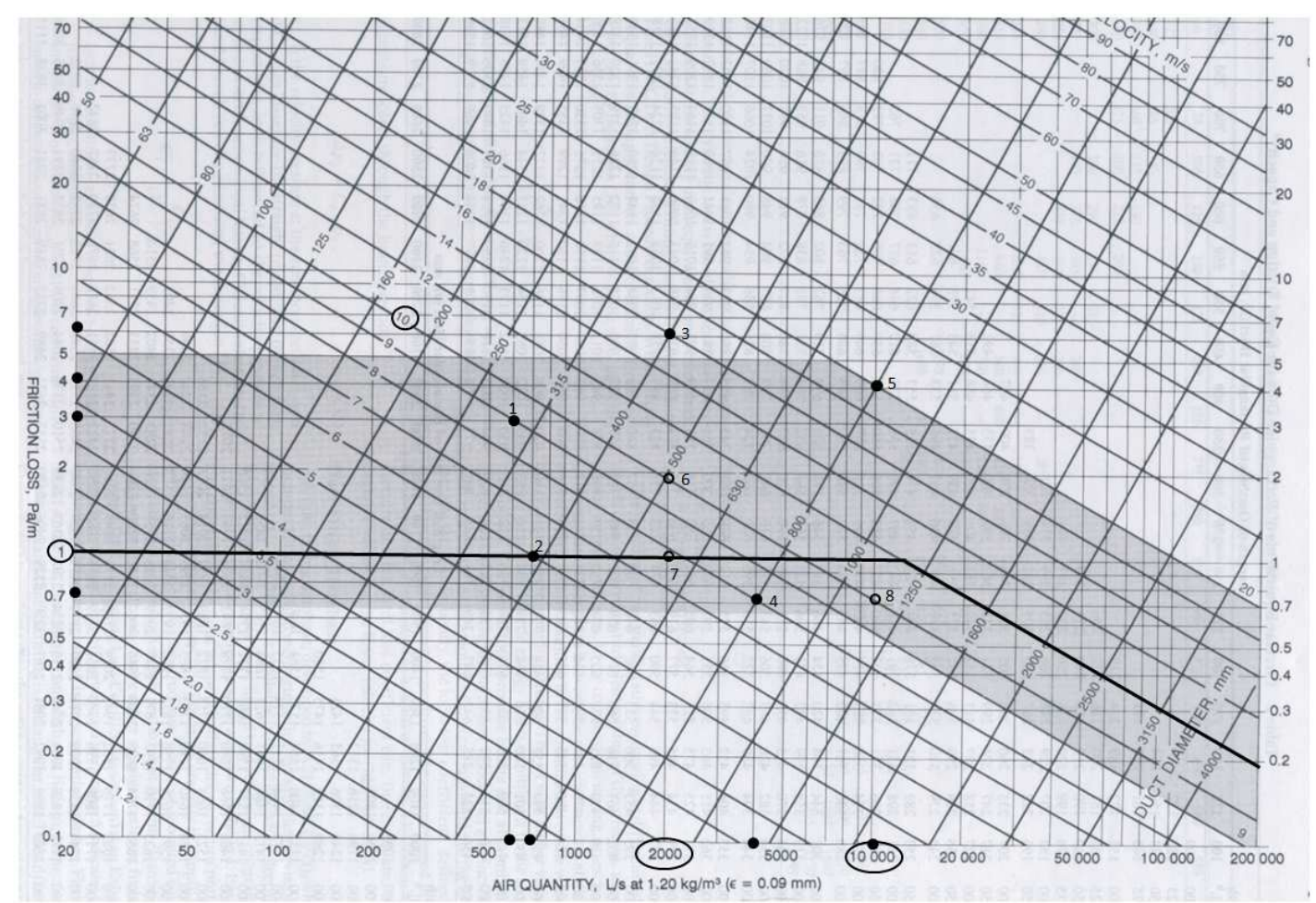

Figure 2. Duct Friction Chart [4]. 


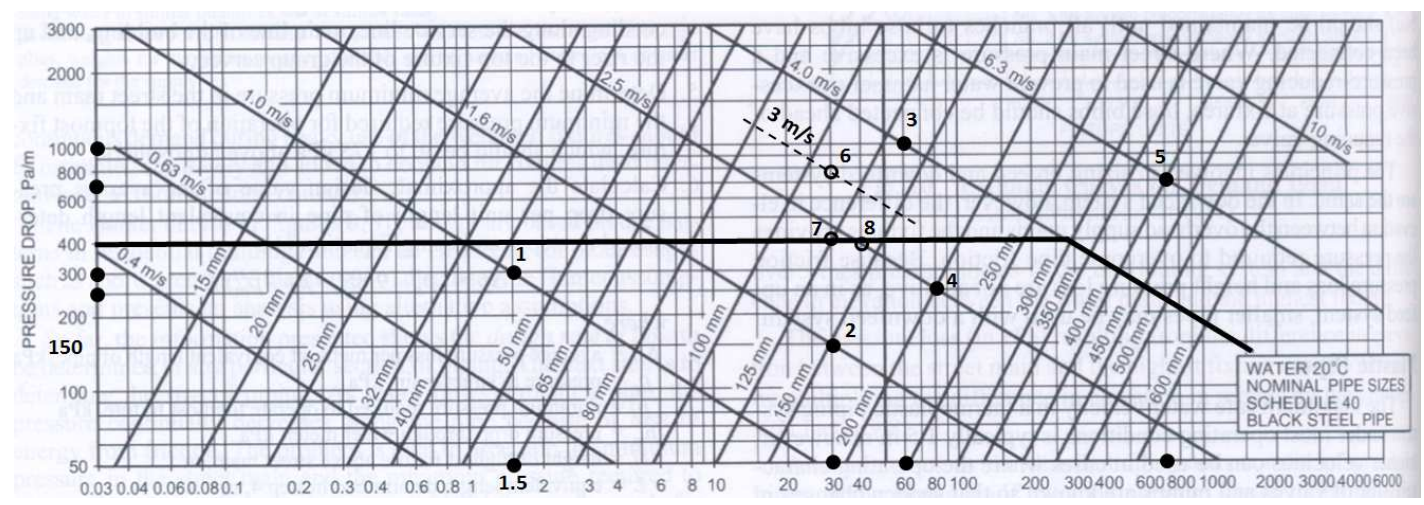

(points 1 5 refer to Table 3) (points 6, 7 refer to Table 5, point 8 refer to Table 6 )

Figure 3. Pipe Friction Chart [5].

\section{Process of Developing an Integrated Equation for Solving Friction Loss}

We tried to develop a duct design software in July 2017, and followed the steps as shown in the example 7 in chapter 21 in 2013 ASHRAE Handbook [6], as depicted in Figure 4. This example presented that the straight-duct friction loss $(\mathrm{Pa} / \mathrm{m})$ and friction factor (f) were calculated by Darcy equation (1) and Colebrook equation (2). The summarized values were shown in column 1 through column 6 in Table 1. Accidentally, we found that all the friction losses (column 6) were different from the friction losses (column 7) obtained from friction chart (Figure 2) except SN 4 and SN 19. We cannot but help ask "Why".

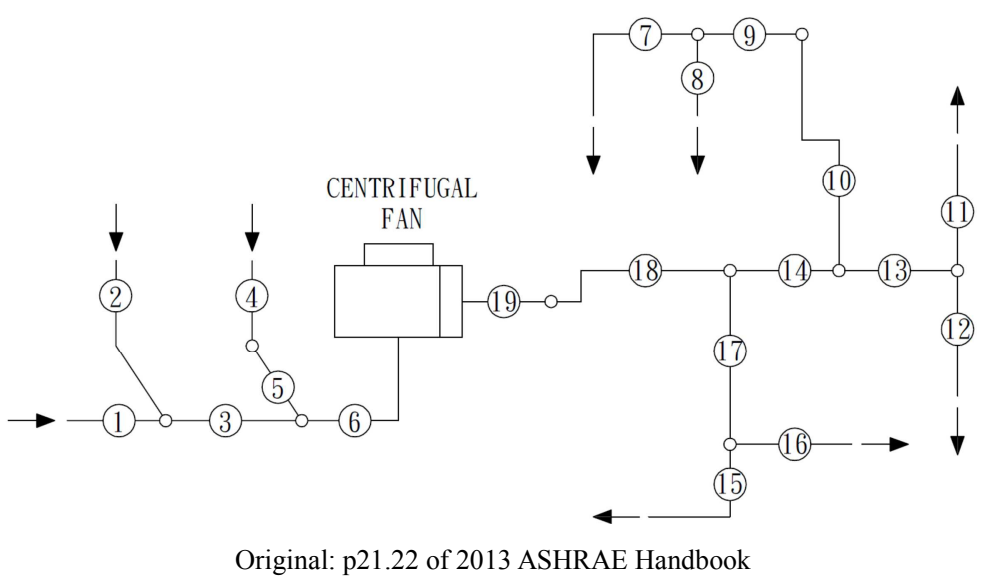

Figure 4. Duct System Example [6].

Table 1. Different Values Obtained by Figure 2, equation 2 and equation 4.

\begin{tabular}{|c|c|c|c|c|c|c|c|}
\hline \multirow{3}{*}{ SN } & \multicolumn{7}{|c|}{ copied from table 8 of ... [6] } \\
\hline & $\varepsilon \mathbf{m m}$ & Q L/s & $\mathrm{V} \mathrm{m} / \mathbf{s}$ & D mm & duct size $\mathbf{m m}$ & friction loss, $\Delta \mathrm{P}_{6} \mathrm{~Pa} / \mathrm{m}$ & read from fig. $2 \mathrm{~Pa} / \mathrm{m}$ \\
\hline & 1 & 2 & 3 & 4 & 5 & 6 & 7 \\
\hline 1 & 0.09 & 700 & 9.0 & 315 & $315 \psi$ & 2.2 & 2.7 \\
\hline 2 & 0.09 & 250 & 6.3 & 224 & $224 \psi$ & 1.8 & 2.0 \\
\hline 3 & 0.09 & 950 & 12.2 & 315 & $315 \psi$ & 3.9 & 4.9 \\
\hline 4 & 0.09 & 950 & 2.6 & 656 & $600 * 600$ & 0.1 & 0.1 \\
\hline 5 & 0.09 & 950 & 7.6 & 400 & $400 \psi$ & 1.2 & 1.5 \\
\hline 6 & 0.09 & 1900 & 11.9 & 450 & $450 \psi$ & 2.5 & 3.0 \\
\hline 7 & 0.09 & 275 & 4.4 & 273 & $250 * 250$ & 0.8 & 0.82 \\
\hline 8 & 0.09 & 275 & 4.4 & 273 & $250 * 250$ & 0.8 & 0.82 \\
\hline 9 & 0.09 & 550 & 4.4 & 381 & $500 * 250$ & 0.6 & 0.5 \\
\hline 10 & 0.09 & 550 & 5.5 & 343 & $400 * 250$ & 0.9 & 0.93 \\
\hline 11 & 0.09 & 475 & 7.6 & 273 & $250 * 250$ & 2.2 & 2.3 \\
\hline 12 & 0.09 & 475 & 7.6 & 273 & $250 * 250$ & 2.2 & 2.3 \\
\hline 13 & 0.09 & 950 & 9.0 & 351 & $420 * 250$ & 2.3 & 2.3 \\
\hline 14 & 0.09 & 1500 & 9.1 & 414 & $660 * 250$ & 1.9 & 1.8 \\
\hline 15 & 0.09 & 200 & 6.7 & 189 & $200 * 150$ & 2.7 & 2.8 \\
\hline 16 & 0.09 & 200 & 6.7 & 189 & $200 * 150$ & 2.7 & 2.8 \\
\hline 17 & 0.09 & 400 & 11.6 & 202 & $230 * 150$ & 7.0 & 7.3 \\
\hline
\end{tabular}




\begin{tabular}{|c|c|c|c|c|c|c|c|}
\hline \multirow{3}{*}{$\mathbf{S N}$} & \multicolumn{7}{|c|}{ copied from table 8 of ... [6] } \\
\hline & $\varepsilon \mathrm{mm}$ & Q L/s & $\mathrm{V} \mathrm{m} / \mathbf{s}$ & D mm & duct size mm & friction loss, $\Delta \mathbf{P}_{6} \mathbf{P a} / \mathrm{m}$ & read from fig. $2 \mathrm{~Pa} / \mathrm{m}$ \\
\hline & 1 & 2 & 3 & 4 & 5 & 6 & 7 \\
\hline 18 & 0.09 & 1900 & 9.5 & 470 & $800 * 250$ & 2.0 & 1.8 \\
\hline 19 & 0.09 & 1900 & 5.3 & 649 & $800 * 450$ & 0.4 & 0.4 \\
\hline
\end{tabular}

Table 1. Continued.

\begin{tabular}{|c|c|c|c|c|c|c|c|}
\hline \multirow{3}{*}{$\mathbf{S N}$} & \multicolumn{4}{|c|}{ from column $6(\Delta \mathrm{P} 6)$} & \multicolumn{3}{|c|}{ from column $11\left(\Delta P_{L}\right)$} \\
\hline & $\begin{array}{l}\text { left side of (eq2) } \\
1 / \sqrt{f}=\end{array}$ & $\begin{array}{l}\text { right side of (eq2) } \\
-2 * \log (\ldots)=\end{array}$ & Error $(\%)(9-8) / 8$ & $\begin{array}{l}\text { by eq }(4) \Delta P_{L} \\
P a / m\end{array}$ & $\begin{array}{l}\text { left side of } \\
(\operatorname{eq} 2) 1 / \sqrt{ } \mathbf{f}=\end{array}$ & $\begin{array}{l}\text { right side of } \\
(\text { eq2 })-2 * \log (\ldots)=\end{array}$ & $\begin{array}{l}\text { Error (\%) } \\
(13-12) / 12 \\
\end{array}$ \\
\hline & 8 & 9 & 10 & 11 & 12 & 13 & 14 \\
\hline 1 & 8.388 & 7.447 & -11.2 & 2.748 & 7.506 & 7.503 & 0.0 \\
\hline 2 & 7.698 & 7.004 & -9.0 & 2.133 & 7.071 & 7.052 & -0.3 \\
\hline 3 & 8.540 & 7.585 & -11.2 & 4.891 & 7.626 & 7.635 & 0.1 \\
\hline 4 & 7.876 & 7.349 & -6.7 & 0.106 & 7.649 & 7.370 & -3.7 \\
\hline 6 & 8.705 & 7.875 & -9.5 & 3.007 & 7.937 & 7.917 & -0.3 \\
\hline 7 & 7.305 & 6.992 & -4.3 & 0.828 & 7.181 & 7.003 & -2.5 \\
\hline 8 & 7.305 & 6.992 & -4.3 & 0.828 & 7.181 & 7.003 & -2.5 \\
\hline 9 & 7.140 & 7.296 & 2.2 & 0.539 & 7.533 & 7.263 & -3.6 \\
\hline 10 & 7.681 & 7.296 & -5.0 & 0.935 & 7.534 & 7.308 & -3.0 \\
\hline 11 & 7.609 & 7.285 & -4.3 & 2.287 & 7.463 & 7.295 & -2.2 \\
\hline 12 & 7.609 & 7.285 & -4.3 & 2.287 & 7.463 & 7.295 & -2.2 \\
\hline 14 & 7.961 & 7.716 & -3.1 & 1.771 & 8.247 & 7.698 & -6.6 \\
\hline 15 & 7.277 & 6.922 & -4.9 & 2.856 & 7.076 & 6.937 & -2.0 \\
\hline 16 & 7.277 & 6.922 & -4.9 & 2.856 & 7.076 & 6.937 & -2.0 \\
\hline 17 & 7.569 & 7.231 & -4.5 & 7.339 & 7.392 & 7.241 & -2.0 \\
\hline 18 & 7.603 & 7.870 & 3.5 & 1.707 & 8.228 & 7.831 & -4.8 \\
\hline 19 & 8.071 & 7.798 & -3.4 & 0.399 & 8.080 & 7.797 & -3.5 \\
\hline
\end{tabular}

※. For standard air : $20^{\circ} \mathrm{C} \mathrm{db}, \rho=1.204 \mathrm{~kg} / \mathrm{m} 3, v=1.508 \mathrm{E}-05 \mathrm{~m}^{2} / \mathrm{s}$

In order to solve this problem, we reversed the calculation steps, i.e., using Darcy equation (1) and the friction loss $\Delta \mathrm{P}_{6}$ in column 6 to obtain friction factor (f) first. Then substitute $\mathrm{f}$ into Colebrook equation (2), and calculate both side values of Colebrook equation (2). The results were shown in columns 8 and 9 in Table 1. Obviously, there is something wrong with friction factor (f) because the left side values (column 8) do not equal the right side values (column 9).

We thought that maybe the friction factors (f) were just roughly read from Moody chart (Figure 1), not really calculated by Colebrook equation (2). Furthermore, in practice, when doing duct design, engineers still do not know the duct diameter yet. How can

$$
\Delta \mathrm{P}_{\mathrm{L}}=\rho^{*}\left(\left(0.0769 / \mathrm{Q}^{0.5 *} \mathrm{~V}^{2.5}\right)+\left(12832.5^{*} \mathrm{v} / \mathrm{Q}^{2} * \mathrm{~V}^{7}+0.2559 * \varepsilon / \mathrm{Q}^{2 *} \mathrm{~V}^{8}\right)^{1 / 3}\right)
$$

where

$\Delta \mathrm{P}_{\mathrm{L}}=$ friction loss $(\mathrm{Pa} / \mathrm{m}) \mathrm{Q}=$ flow rate $(\mathrm{L} / \mathrm{s}) \mathrm{V}=$ velocity $(\mathrm{m} / \mathrm{s})$

\section{Verify the Validity of Equation (4)}

Is Equation (4) correct for practical applications? The following three ways were used for verification.

Way 1: Verification by Darcy's \& Colebrook's Equations

Equation (4) was used to calculate friction loss $(\mathrm{Pa} / \mathrm{m})$ for the example values in Table 1 . The results $\left(\Delta \mathrm{P}_{\mathrm{L}}\right)$ are shown in column 11 in Table 1 . These calculated friction losses $(\mathrm{Pa} / \mathrm{m})$ are substituted into Darcy equation (1) to obtain friction factor (f). Then, substituted f, Re and $\varepsilon / \mathrm{D}$ into Colebrook equation we use Colebrook equation to obtain friction factor (f)? Therefore, we tended to think from engineers' viewpoints, and hoped to find out if there is a better method to calculate friction factor (f) without diameter.

The process of solving problems is something like a reverse-thinking logic. We tried Steffensen method, iterative method and some mathematic techniques to solve Colebrook equation (2). After doing huge trial and error processes, we eventually obtained one integrated equation (4) by computerized programs. Equation (4) is a one-step method to calculate duct/pipe friction loss $(\mathrm{Pa} / \mathrm{m})$.
(2). The calculated values for both sides of Colebrook equation (2) are shown in columns 12 and 13 in Table 1. Comparing the error (\%) shown in column 10 and column 14, it is found that accuracy of Equation (4) is believable.

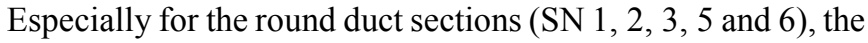
errors are less than $0.3 \%$.

Way 2: Verification by Moody Chart

Equation (4) does not need friction factor (f) for calculating friction loss $(\mathrm{Pa} / \mathrm{m})$. Nevertheless, for comparing with the friction factor (f) obtained from Moody chart, we rewrite Darcy equation (1) as the following equation for obtaining friction factor $f\left(\Delta P_{L}\right)$.

$$
\mathrm{f}\left(\Delta \mathrm{P}_{\mathrm{L}}\right)=0.07136 * \Delta \mathrm{P}_{\mathrm{L}} * \mathrm{Q}^{0.5} / \rho / \mathrm{V}^{2.5}
$$

where 
$\mathrm{f}\left(\Delta \mathrm{P}_{\mathrm{L}}\right)=$ friction factor based on $\Delta \mathrm{P}_{\mathrm{L}}$

$\Delta \mathrm{P}_{\mathrm{L}}=$ friction loss $(\mathrm{Pa} / \mathrm{m})$ based on Equation (4)

Moody chart can be used to verify Equation (4) by four steps. First of all, with given flow rate (Q) and velocity (V) to calculate friction loss $\left(\Delta \mathrm{P}_{\mathrm{L}}\right)$ by Equation (4). Secondly, to calculate friction factor $\left(\mathrm{f}\left(\Delta \mathrm{P}_{\mathrm{L}}\right)\right)$ by equation (5). Thirdly, to calculate Reynolds number ( $\mathrm{Re}$ ) by equation (3) and relative roughness $(\varepsilon / D)$, and plot the junction point on Moody chart (Figure 1). Finally, to check if $\mathrm{f}\left(\Delta \mathrm{P}_{\mathrm{L}}\right)$ equals friction factor $(\mathrm{f})$ on Moody chart (Figure 1).

For galvanized steel duct $(\varepsilon=0.09)$ and standard air, the calculated $\mathrm{f}\left(\Delta \mathrm{P}_{\mathrm{L}}\right)$ values are shown in column 10 in Table 2.
Although you can only read an approximate $f$ value from Moody chart, it is obvious to see the contrast between the $f$ $\left(\Delta \mathrm{P}_{\mathrm{L}}\right)$ values (column 10) and the friction factor (f) on Moody chart (Figure 1 points $1 \sim 5)$. You can clearly see that $\mathrm{f}\left(\Delta \mathrm{P}_{\mathrm{L}}\right)$ values (column 10) and f values (column11) in Table 2 are identical.

By the same token, for commercial steel pipe $\mathrm{SCH} 40$ ( $\varepsilon=0.065)$ and $20^{\circ} \mathrm{C}$ water, using the $\varepsilon / \mathrm{D}$ (column 8) and $\mathrm{Re}$ values (column 9$)$ in Table 3 , you can see both $\mathrm{f}\left(\Delta \mathrm{P}_{\mathrm{L}}\right.$, column 10) and f (column 11) read from Moody chart are almost the same values. That means, Equation (4) is suitable for calculating pipe friction loss $(\mathrm{Pa} / \mathrm{m})$ also.

Table 2. Duct Verification Example by Moody Chart.

\begin{tabular}{|c|c|c|c|c|c|c|c|c|c|c|c|c|}
\hline \multicolumn{6}{|c|}{ Inputs } & \multicolumn{5}{|c|}{ Outputs } & \multirow{2}{*}{$\begin{array}{l}\text { Read from } \\
\text { Figure } 1 \text { f }\end{array}$} & \multirow{2}{*}{$\begin{array}{l}\text { Read from } \\
\text { Figure } 2 \mathrm{~Pa} / \mathrm{m}\end{array}$} \\
\hline SN & $\varepsilon \mathrm{mm}$ & $\rho \mathrm{kg} / \mathrm{m}^{3}$ & $v^{2} \mathrm{~m}^{2} / \mathrm{s}$ & $\mathbf{Q} \mathbf{L} / \mathbf{s}$ & $\mathrm{V} \mathrm{m} / \mathbf{s}$ & $\begin{array}{l}\Delta \mathbf{P}_{\mathrm{L}} \\
\mathrm{Pa} / \mathrm{m}\end{array}$ & D mm & by $1 / 7 \varepsilon / D$ & $\begin{array}{l}\text { by eq (3) } \\
\text { Re }\end{array}$ & $\begin{array}{l}\text { by eq (5) } \\
f\left(\Delta P_{L}\right)\end{array}$ & & \\
\hline & 1 & 2 & 3 & 4 & 5 & 6 & 7 & 8 & 9 & 10 & 11 & 12 \\
\hline 1 & 0.090 & 1.204 & $1.508 \mathrm{E}-05$ & 600 & 9.0 & 3.021 & 291 & 3.09E-04 & $1.74 \mathrm{E}+05$ & 0.018 & $\fallingdotseq 0.018$ & $\fallingdotseq 3.0$ \\
\hline 2 & 0.090 & 1.204 & $1.508 \mathrm{E}-05$ & 700 & 6.0 & 1.000 & 385 & 2.34E-04 & $1.53 \mathrm{E}+05$ & 0.018 & $\fallingdotseq 0.018$ & $\fallingdotseq 1.0$ \\
\hline 3 & 0.090 & 1.204 & $1.508 \mathrm{E}-05$ & 2000 & 16.0 & 6.158 & 399 & $2.26 \mathrm{E}-04$ & $4.23 \mathrm{E}+05$ & 0.016 & $\fallingdotseq 0.016$ & $\fallingdotseq 6.2$ \\
\hline 4 & 0.090 & 1.204 & $1.508 \mathrm{E}-05$ & 4000 & 8.0 & 0.707 & 798 & $1.13 \mathrm{E}-04$ & $4.23 \mathrm{E}+05$ & 0.015 & $\fallingdotseq 0.015$ & $\fallingdotseq 0.71$ \\
\hline 5 & 0.090 & 1.204 & $1.508 \mathrm{E}-05$ & 10000 & 20.0 & 4.101 & 798 & $1.13 \mathrm{E}-04$ & $1.06 \mathrm{E}+06$ & 0.014 & $\fallingdotseq 0.014$ & $\fallingdotseq 4.1$ \\
\hline
\end{tabular}

※ Compare SN1 5 to points $1 \sim 5$ in Figure 1 and Figure 2

Table 3. Pipe Verification Example by Moody Chart.

\begin{tabular}{|c|c|c|c|c|c|c|c|c|c|c|c|c|}
\hline \multicolumn{6}{|c|}{ Inputs } & \multicolumn{5}{|c|}{ Outputs } & \multirow{2}{*}{$\begin{array}{l}\text { Read from } \\
\text { Figure } 1 \text { f }\end{array}$} & \multirow{2}{*}{$\begin{array}{l}\text { Read from } \\
\text { Figure } 3 \mathrm{~Pa} / \mathrm{m}\end{array}$} \\
\hline SN & $\varepsilon \mathrm{mm}$ & $\rho \mathrm{kg} / \mathrm{m}^{3}$ & $v \mathrm{~m}^{2} / \mathrm{s}$ & Q L/s & $\mathrm{V} \mathrm{m} / \mathbf{s}$ & $\begin{array}{l}\Delta \mathbf{P}_{\mathrm{L}} \\
\mathrm{Pa} / \mathrm{m}\end{array}$ & D mm & by $1 / 7 \varepsilon / D$ & $\begin{array}{l}\text { by eq (3) } \\
\text { Re }\end{array}$ & $\begin{array}{l}\text { by eq (5) } \\
f\left(\Delta P_{L}\right)\end{array}$ & & \\
\hline & 1 & 2 & 3 & 4 & 5 & 6 & 7 & 8 & 9 & 10 & 11 & 12 \\
\hline 1 & 0.065 & 998.2 & $1.004 \mathrm{E}-06$ & 1.5 & 1.0 & 298.1 & 44 & $1.49 \mathrm{E}-03$ & $4.35 \mathrm{E}+04$ & 0.026 & $\fallingdotseq 0.0255$ & $\fallingdotseq 300$ \\
\hline 2 & 0.065 & 998.2 & $1.004 \mathrm{E}-06$ & 30.0 & 1.6 & 150.8 & 155 & $4.21 \mathrm{E}-04$ & $2.46 \mathrm{E}+05$ & 0.018 & $\fallingdotseq 0.0180$ & $\fallingdotseq 150$ \\
\hline 3 & 0.065 & 998.2 & $1.004 \mathrm{E}-06$ & 60.0 & 4.0 & 1028.2 & 138 & $4.70 \mathrm{E}-04$ & $5.51 \mathrm{E}+05$ & 0.018 & $\fallingdotseq 0.0175$ & $\fallingdotseq 1000$ \\
\hline 4 & 0.065 & 998.2 & $1.004 \mathrm{E}-06$ & 80.0 & 2.5 & 257.7 & 202 & $3.22 \mathrm{E}-04$ & $5.03 \mathrm{E}+05$ & 0.017 & $\fallingdotseq 0.0165$ & $\fallingdotseq 255$ \\
\hline 5 & 0.065 & 998.2 & $1.004 \mathrm{E}-06$ & 700.0 & 6.3 & 743.9 & 376 & $1.73 \mathrm{E}-04$ & $2.36 \mathrm{E}+06$ & 0.014 & $\fallingdotseq 0.0137$ & $\fallingdotseq 720$ \\
\hline
\end{tabular}

※ Compare SN1 5 to the points $1 \sim 5$ in Figure 3

Way 3: Verification by Duct and Pipe Friction Charts

Figure 2 is the air friction chart suitable for galvanized steel round duct $(\varepsilon=0.09 \mathrm{~mm})$ and standard air $\left(20^{\circ} \mathrm{C}, \rho=1.204\right.$ $\left.\mathrm{kg} / \mathrm{m}^{3}, \quad v=1.508^{*} 10^{-5} \mathrm{~m}^{2} / \mathrm{s}\right)$. The friction losses $\left(\Delta \mathrm{P}_{\mathrm{L}}\right)$ calculated by Equation (4) are shown in column 6 in Table 2, and the coincident points $(1 \sim 5)$ are plotted on air friction chart (Figure 2). You can see the $\Delta \mathrm{P}_{\mathrm{L}}$ values (column 6) calculated by Equation (4) are almost the same as the friction loss (column 12) obtained by Q and V from Figure 2.

Similarly, Equation (4) can be used for the liquid Pipes. Figure 3 is the water friction chart suitable for $20^{\circ} \mathrm{C}$ water $\left(\rho=998.2 \mathrm{~kg} / \mathrm{m}^{3}, v=1.004 * 10^{-6} \mathrm{~m}^{2} / \mathrm{s}\right)$. The friction loss $\left(\Delta \mathrm{P}_{\mathrm{L}}\right)$ calculated by Equation (4) is shown in column 6 in Table 3, and the coincident points (1 5) are plotted on water friction chart (Figure 3). You can see the $\Delta \mathrm{P}_{\mathrm{L}}$ values (column 6) calculated by Equation (4) are almost the same as the friction loss (column 12) obtained by Q and V from Figure 3 also.

Therefore, the reliability of Equation (4) is verified by duct friction chart (Figure 2) and water pipe friction chart (Figure 3).

\section{Darcy \& Colebrook Equations vs. Equation (4)}

Usually HVAC engineers determine flow rate (Q) based on cooling load calculation first. Duct/pipe diameter is still unknown at that time. Hence, it is not practical to use Moody chart (Figure 1) to obtain exact friction factor (f), let alone Colebrook equation (2). The difference between Darcy's \& Colebrook's equations and Equation (4) infers that the former is better for studying the relations between friction factor ( $\mathrm{f}$ ), Reynolds number (Re), relative roughness $(\varepsilon / \mathrm{D})$ and friction loss $(\mathrm{Pa} / \mathrm{m})$, and Equation (4) is better for realistic duct/pipe designs. You can put different $\rho, v$, $\varepsilon$, and $\mathrm{D}$ values into Colebrook equation (2) to obtain friction factor (f) iteratively, and use Darcy equation (1) to obtain friction loss $(\mathrm{Pa} / \mathrm{m})$. On the contrary, equation (4) is a one-step equation to obtain friction loss $(\mathrm{Pa} / \mathrm{m})$ by the known flow rate $(\mathrm{Q})$ and velocity $(\mathrm{V})$ that are determined by (HVAC) engineers.

The comparison between Darcy \& Colebrook equations and equation (4) is shown in Table 4. 
Table 4. Darcy \& Colebrook Equations vs. Equation (4).

\begin{tabular}{lll}
\hline & Darcy \& Colebrook equations & Equation (4) \\
\hline parameters for getting $\mathrm{Pa} / \mathrm{m}$ & $\rho, v, \varepsilon, \mathrm{D}, \mathrm{Re} \& \mathrm{f}$ & $\rho, v, \varepsilon, \mathrm{Q} \& \mathrm{~V}$ \\
calculating steps & $\varepsilon / \mathrm{D} \rightarrow \mathrm{Re} \rightarrow \mathrm{f} \rightarrow \mathrm{Pa} / \mathrm{m}$ & one step $\rightarrow \mathrm{Pa} / \mathrm{m}$ \\
calculation method & by iterative method & by hand calculator \\
suitable for & duct and pipe with the most accuracy & duct and pipe with accuracy $\pm 2 \%$ \\
fault & can't be done by hand calculator & may not reliable for $\mathrm{Re}<10,000$ \\
\hline
\end{tabular}

\section{Equation (4) Apply to Equal Friction Loss Method}

Engineers usually use given flow rate to decide duct/pipe diameter by friction chart. The most common design method is equal friction loss method. Actually, Equation (4) can be used for equal friction loss method by simple trial \& error process. Here are the steps for applying Equation (4) to equal friction loss method.

Initially, you can assume friction loss $1 \mathrm{~Pa} / \mathrm{m}$ (Figure 2) for duct design and $400 \mathrm{~Pa} / \mathrm{m}$ (Figure 3) for pipe design. Then, plot the junction point of the assumed friction loss $(\mathrm{Pa} / \mathrm{m})$ and flow rate $(\mathrm{Q})$ to obtain diameter. For duct design, you can try $\mathrm{V}=10 \mathrm{~m} / \mathrm{s}$ first to see if friction loss equals $1.0 \mathrm{~Pa} / \mathrm{m}$ (target). If the first trail friction loss is larger than $1.0 \mathrm{~Pa} / \mathrm{m}$, lower the velocity and try again until the target friction loss $(1.0 \mathrm{~Pa} / \mathrm{m})$ is obtained. Table 5 is the example showing the simple trail \& error steps for duct and pipe designs; please refer to points 6,7 in Figure 2 and Figure 3.

Table 5. Method for Applying Equation (4) to Equal Friction Method.

\begin{tabular}{|c|c|c|c|c|c|c|c|c|c|c|c|c|c|c|}
\hline \multirow{2}{*}{$\begin{array}{l}\text { given } \\
\mathrm{Q}(\mathrm{L} / \mathrm{s})\end{array}$} & \multicolumn{3}{|c|}{ initial trial (point 6) } & \multicolumn{3}{|c|}{ second trial } & \multicolumn{3}{|c|}{ third trial } & \multicolumn{5}{|c|}{ lucky guess (point 7) } \\
\hline & $\mathrm{V}(\mathrm{m} / \mathrm{s})$ & $\rightarrow$ & $\mathrm{Pa} / \mathrm{m}$ & $\mathrm{V}(\mathrm{m} / \mathrm{s})$ & $\rightarrow$ & $\mathrm{Pa} / \mathrm{m}$ & $\mathrm{V}(\mathrm{m} / \mathrm{s})$ & $\rightarrow$ & $\mathrm{Pa} / \mathrm{m}$ & $\mathrm{V}(\mathrm{m} / \mathrm{s})$ & $\rightarrow$ & $\mathrm{Pa} / \mathrm{m}$ & $\rightarrow$ & $\mathrm{D}(\mathrm{mm})$ \\
\hline 2,000 & $\begin{array}{l}10.00 \\
\uparrow \text { For duc }\end{array}$ & $\begin{array}{l}\rightarrow \\
\text { sign }\end{array}$ & 1.88 & $\begin{array}{l}9.00 \\
(\downarrow \text { For pi }\end{array}$ & $\begin{array}{l}\rightarrow \\
\text { ign) }\end{array}$ & 1.45 & 8.00 & $\rightarrow$ & 1.08 & 7.77 & $\rightarrow$ & 1.00 & $\rightarrow$ & 572 \\
\hline 30 & 3.00 & $\rightarrow$ & 751.85 & 2.5 & $\rightarrow$ & 470.93 & 2 & $\rightarrow$ & 266.18 & 2.346 & $\rightarrow$ & 400.18 & $\rightarrow$ & 128 \\
\hline
\end{tabular}

Normally, the values $\rho$, vandecan be found in common fluid mechanics books. Thus, equation (4) can be widely applied to most fluids and materials. Table 6 shows some applications for different fluids $(\rho)$ and materials $(\varepsilon)$. You can see that the friction loss $(\mathrm{Pa} / \mathrm{m}$, column 6) is variable depending on different fluids and materials (see Column 11).

Table 6. Applications for Different Fluids and Materials.

\begin{tabular}{|c|c|c|c|c|c|c|c|c|c|c|c|}
\hline \multicolumn{6}{|c|}{ Inputs } & \multicolumn{4}{|l|}{ Outputs } & \multirow{2}{*}{$\begin{array}{l}\text { By eq (5) } \\
\text { f }\end{array}$} & \multirow{2}{*}{ Remarks } \\
\hline \multirow{2}{*}{ SN } & $\varepsilon \mathrm{mm}$ & $\rho \mathrm{kg} / \mathrm{m}^{3}$ & $v^{2} \mathrm{~m}^{2} / \mathrm{s}$ & Q L/s & $\mathrm{V} \mathrm{m} / \mathbf{s}$ & $\Delta \mathbf{P}_{\mathrm{L}} \mathrm{Pa} / \mathrm{m}$ & D mm & by $1 / 7 \varepsilon / D$ & by eq (3) $\mathrm{Re}$ & & \\
\hline & 1 & 2 & 3 & 4 & 5 & 6 & 7 & 8 & 9 & 10 & 11 \\
\hline 1 & 0.09 & 1.204 & $1.508 \mathrm{E}-05$ & 10000 & 10 & 0.713 & 1128 & $7.98 \mathrm{E}-05$ & $7.49 \mathrm{E}+05$ & 0.0134 & $\varepsilon=0.09$, standard air $\left(20^{\circ} \mathrm{C}, 0 \% \mathrm{rh}\right)$ \\
\hline 2 & 0.12 & 1.204 & $1.508 \mathrm{E}-05$ & 10000 & 10 & 0.737 & 1128 & $1.06 \mathrm{E}-04$ & $7.49 \mathrm{E}+05$ & 0.0138 & $\varepsilon=0.12$, standard air $\left(20^{\circ} \mathrm{C}, 0 \% \mathrm{rh}\right)$ \\
\hline 3 & 0.09 & 1.100 & $1.757 \mathrm{E}-05$ & 10000 & 10 & 0.660 & 1128 & $7.98 \mathrm{E}-05$ & $6.42 \mathrm{E}+05$ & 0.0135 & $\varepsilon=0.09$, heating air $\left(45^{\circ} \mathrm{C}, 25 \% \mathrm{rh}\right)$ \\
\hline 4 & 0.12 & 1.100 & $1.727 \mathrm{E}-05$ & 10000 & 10 & 0.681 & 1128 & $1.06 \mathrm{E}-04$ & $6.42 \mathrm{E}+05$ & 0.0135 & $\varepsilon=0.12$, heating air $\left(45^{\circ} \mathrm{C}, 25 \% \mathrm{rh}\right)$ \\
\hline 5 & 0.09 & 1.042 & $1.877 \mathrm{E}-05$ & 5000 & 10 & 0.956 & 798 & $1.13 \mathrm{E}-04$ & $4.25 \mathrm{E}+05$ & 0.0146 & $\varepsilon=0.09$, kitchen hood $\left(50^{\circ} \mathrm{C}, 100 \% \mathrm{rh}\right)$ \\
\hline 6 & 0.12 & 1.042 & $1.877 \mathrm{E}-05$ & 5000 & 10 & 1.503 & 798 & $1.50 \mathrm{E}-04$ & $4.25 \mathrm{E}+05$ & 0.0150 & $\varepsilon=0.12$, kitchen hood $\left(50^{\circ} \mathrm{C}, 100 \% \mathrm{rh}\right)$ \\
\hline \multicolumn{12}{|c|}{$\uparrow$ For Air ( $\downarrow$ For water) } \\
\hline 7 & 0.065 & 998.2 & $1.003 \mathrm{E}-06$ & 40 & 2.5 & 394.348 & 143 & $4.55 \mathrm{E}-04$ & $3.56 \mathrm{E}+05$ & 0.0180 & $\varepsilon=0.065,20^{\circ} \mathrm{C}$ water \\
\hline 8 & 0.065 & 999.7 & $1.300 \mathrm{E}-06$ & 40 & 2.5 & 401.207 & 143 & $4.55 \mathrm{E}-04$ & $2.74 \mathrm{E}+05$ & 0.0183 & $\varepsilon=0.065,10^{\circ} \mathrm{C}$ cooling water \\
\hline 9 & 0.150 & 983.2 & $4.740 \mathrm{E}-07$ & 40 & 2.5 & 451.353 & 143 & $1.05 \mathrm{E}-03$ & $7.53 \mathrm{E}+05$ & 0.0210 & $\varepsilon=0.15,60^{\circ} \mathrm{C}$ heating water \\
\hline
\end{tabular}

Note 1: SN1 can refer to point 8 in Figure 2, SN7 can refer to point 8 in Figure 3.

Note 2: duct $\varepsilon$ values: galvanized steel round (0.09), galvanized steel spiral (0.12)

Note 3: pipe $\varepsilon$ values: commercial steel SCH40 (0.065), galvanized steel $(0.15)$

\section{Conclusions}

The emphasis in this article is to verify if Equation (4) is coincident with Darcy and Colebrook equations. We own an HVAC\&R consultancy firm and have the opportunity to contact many real duct/pipe projects. Equation (4) has been successfully applied to dozens of actual duct and pipe design projects since 2018. For the Reynolds number $(\mathrm{Re})$ is greater than 10,000 (i.e. turbulent flow), our analysis indicates that the friction losses ( $\mathrm{Pa} / \mathrm{m})$ obtained from Equation (4) is within $\pm 2.0 \%$ of those obtained from Darcy's and Colebrook's equations. Therefore, the accuracy of equation (4) is good enough for engineers doing duct/pipe designs. Normally, engineers use given $Q$ and $V$ to obtain diameter $\mathrm{D}$ and friction loss $\Delta P_{f}$. We are professional engineers (P. E.) and satisfy with equation (4) applications. Besides, in real life duct/pipe applications, the Reynolds number is greater than 10,000 (see the Re in tables 2, 3,6). We do not have the chance to try the situation with $\mathrm{Re} \leqq 10,000$. Maybe equation (4) is not reliable enough if it is used for the Reynolds number lesser than 10,000 . For someone needs to differentiate 
laminar, transition and turbulent flow regions (see figure 1) when doing fluid dynamics research, you can use EXCEL worksheet to calculate $\varepsilon / \mathrm{D}, \mathrm{Re}$, f and $\Delta \mathrm{P}_{\mathrm{L}}$ as we do in Table 6 . Then, you can compare these values with the values obtained from equations (1), (2) and (3), or from Moody chart (Figure 1). There are many approximations of Colebrook's equation mentioned in public references, such as references from [7] to [15]. All these equations still need to calculate Reynolds Number (Re) first and just to solve Colebrook equation only. Not a similar equation like equation (4) using flow rate (Q) and velocity (V) to solve both of Colebrook equation and Darcy equation is found. Hence, we decide to release this article and let more engineers share our effort. Equation (4) can be the handy alternative for engineers to do realistic duct and pipe designs.

\section{References}

[1] Brown, G. O. "The History of the Darcy-Weisbach Equation for pipe Flow Resistance" Environmental and Water Resources History. American Society of Civil Engineers. Pp. 34-43. ISBN978-0-7844-0650-2, 2003.

[2] Colebrook, C. F.: Turbulent flow in pipes, with particular reference to the transition region between the smooth and rough pipe laws, Journal of the Institution of Civil Engineers, England, Vol. 11, No.4, 1939.

[3] Moody, L. F.: Friction factors for pipe flow Transactions of the ASME. Vol. 66, No.8, 1944.

[4] ASHRAE Handbook 2017, Figure 10 (p21.9) in Chapter 21.
[5] ASHRAE Handbook 2017, Figure 4 in Chapter 22.

[6] ASHRAE Handbook 2013, Example 7 (p21.22) in Chapter 21.

[7] Moody, L. F.: An approximate formula for pipe friction factors, Transactions of the ASME, Vol. 69, 1947.

[8] Zigrang, D. J. and Sylvester, N. D.: Explicit approximations to the solution of Colebrook's friction factor equation, AIChE Journal, Vol. 28, No.3, 1982.

[9] Haaland, S. E.: Simple and explicit formulas for the friction factor in turbulent pipe flow, Transactions of the ASME, Journal of Fluids Engineering, Vol. 105, No.1, 1983.

[10] Romeo, Royo, and Monzon, "Improved explicit equations for estimation of friction factor in rough and smooth pipes" 2002.

[11] Lester, T. "Solving for Friction Factor." ASHRAE Journal July, 2003.

[12] Avci and Karagoz, "A novel Explicit Equation for friction factor in smooth and rough pipes", ASME J. Fluids Eng., 131, 2009.

[13] More, A. A. "Analytical solutions for the Colebrook and White equation and for pressure drop in ideal gas flow in pipes". Chemical Engineering Science. 61 (16), 2006.

[14] Fang, X, Xua, Y. and Zhou Z., "New correlations of single-phase friction factor for turbulent pipe flow and evaluation of existing single-phase friction factor correlations", Nuclear Engineering and Design, Vol. 241, No. 3, 2011.

[15] Brkic, Dejan, Review of explicit approximations to the Colebrook relation for the flow friction, Journal of Petroleum Science and Engineering, 77 (1), Elsevier, 2011. 